\title{
Okul Yöneticilerinin Müzakere Becerilerinin Yordayıcısı Olarak Etkileme Davranışları*
}

\author{
Influencing Behaviors of School Administrators as A Predictor of Negotiation Skills
}

\author{
Adnan IRMAK \\ Blm.Uzm. - Öğretmen, MEB - İbrahim Yapıcı İlkokulu, \\ irmakadnan@gmail.com \\ https://orcid.org/0000-0003-4702-1688 \\ Ercan YILMAZ \\ Prof. Dr., Necmettin Erbakan Üniversitesi, \\ Ahmet Keleşoğlu Ĕgitim Fakültesi, \\ Eğitim Bilimleri Bölümü, ercanyilmaz70@gmail.com \\ https://orcid.org/0000-0003-4702-1688
}

Makale Başvuru Tarihi: 13.03.2021

Makale Kabul Tarihi: 27.05.2021

Makale Türü: Araştırma Makalesi

\section{ÖZET}

\begin{abstract}
Anahtar
Kelimeler:

Müzakere,

Müzakere

Becerileri,

Etkileme

Davranışları,

Okul Yöneticileri, olup nicel bir araştırmadır. Araştırmanın çalışma grubuna 2019 -2020 ĕgitim öğretim yılı Konya İl Milli Eğitim Müdürlüğüne bă̆lı kamu okullarında görev yapan 736 öğretmen katılmıştır. Araştırmada okul yöneticilerinin müzakere becerileri düzeyini belirlemek üzere "Müzakere Becerileri Ölçeği” kullanılmiştır. Okul yöneticilerinin etkileme davranış düzeylerini belirlemek amacılla da "Etkileme Davranış Ölçeği", kullanılmıştır. Demografik özelliklerin betimlenmesinde kategorik ikili karşılaştırmada t testi; çoklu karşılaştırmalarda ise tek yönlü varyans analizi yapılmıştır. Araştırmada iki değişken arasındaki ilişkiyi belirlemek üzere korelasyon analizi yapılmıştır. Ayrıca bağımlı değişkenin bă̆ımsız değişken üzerinde etkisini belirlemek üzere regresyon analizine başvurulmuştur. Analiz sonucunda ögretmen algılarına göre okul yöneticilerinin müzakere becerilerinde, cinsiyet durumu ve okul türü durumu değişkenine göre anlamlı bir farklılaşma bulunurken; kıdem durumu ve öğrenim durumu değişkenine göre anlamlı bir farklılaşma bulunmamıştır. Öğretmen algllarına göre okul yöneticilerinin müzakere becerileri alt boyutlarıyla etkileme davranışları alt boyutları arasında anlamlı bir ilişki tespit edilmiştir. Öğretmen algılarına göre okul yöneticilerinin etkileme davranışlarının müzakere becerileri alt boyutlarından güven ortamı oluşturma ve çözümden yana olma alt boyutunu yordadiğı tespit edilmiştir. Araştırmanın bulgularından yola çıkarak sonuç ve önerilere yer verilmiştir.
\end{abstract}

Keywords:

Negotiation,

Negotiation Skills,

Influencing

Behaviors,

School

Administrators,

Bu çalışma, öğretmen algılarına göre okul yöneticilerinin müzakere becerilerinin yordayıcısı olarak etkileme davranışlarını incelemek üzere yapılmıştır. Araştırma, nedensel karşılaştırma ve ilişkisel tarama modelinde

\section{ABSTRACT}

This study was conducted to examine influencing behaviors of school administrators as a predictor of negotiation skills according to teachers' perceptions. The research is a quantitative research in causal comparison and relational scanning model. The study group of the study was attended by 736 teachers working in public schools affiliated to Konya Provincial Directorate of National Education for the 2019-2020 academic year. In the study, "Negotiation Skills Scale" was used to determine the negotiation skills level of school administrators. "Influencing Behavior Scale" was used to determine the influencing behavior levels of school administrators. T test in categorical paired comparison in describing demographic characteristics; one-way analysis of variance was performed in multiple comparisons. Correlation analysis was conducted to determine the relationship between two variables in the study. In addition, regression analysis was used to determine the effect of the dependent variable on the independent variable. As a result of the analysis, there was a significant difference in the negotiation skills of school administrators according to the teachers' perceptions according to the gender and school type variables; There was no significant difference in terms of seniority and educational status variables. According to teachers' perceptions, a significant relationship was found between the negotiation skills sub-dimensions of school administrators and the influencing behaviors sub-dimensions. According to teachers' perceptions, it was determined that influencing behaviors of school administrators predicted the sub-dimension of negotiation skills, creating an atmosphere of trust and being in favor of solution. Based on the findings of the research, results and suggestions are given.

* Bu makale Prof. Dr. Ercan YILMAZ (1. yazar) danışmanlığında, Blm. Uzm. Adnan IRMAK (2. yazar) tarafından hazırlanarak 2020 yılında Necmettin Erbakan Üniversitesi Eğitim Bilimleri Enstitüsü tarafindan kabul edilen "Okul Yöneticilerinin Etkileme Davranışlarının Müzakere Becerilerine Etkisi” adlı yüksek lisans tez çalışmasından yararlanılarak hazırlanmıştır. 


\section{GIRISS}

Gündelik hayatın içinde bireyler arası etkileşimin kaçınılmazlığı, genel kabul gören bir görüştür. Etkileşim sonucunda sözel ve sözel olmayan iletişim üzerinden insanlar, birbirlerine sergiledikleri davranış ve verdikleri tepkiler neticesinde çatışma yaşayabilmektedir (Gökyer, 2017:392). Bireysel ve örgütsel anlamda hem olumlu hem de olumsuz etkileri bulunan çatışmanın nedenlerini ve süreçlerini ortaya çıkarmak, yöneticilere etkin yönetim, çalışanlara ise bireysel gelişim sunması açısından önemlidir (Artan, 2002:201). Yönetici ve çalışanlar, çatışmaların nedenlerini veya geliştirdikleri uygun çözüm önerilerini ortaya koyarken birbirleriyle müzakere halinde olmaktadır. Müzakere hem sözlü hem de sözlü olmayan yollarla bilgi alışverişinde bulunma eylemleri olarak tanımlanmaktadır (Küden, 2016:7).

Alan yazın incelendiğinde eğitim alanında yapılan müzakere araştırmalarının ulusal kaynakların müzakere becerileri (müzakereci), uluslararası kaynakların ise müzekereye etki eden kavramlar (müzakere süreci) üzerinde yoğunlaştığı görülmektedir. Yıldırım vd. (2013:2287), çalışmalarında okul müdürlerinin müzakere becerilerinin orta düzeyde olduğu dolayısıyla okul müdürlerinin müzakere becerilerinin yeterli veya yetersiz olarak kabul edilemeyeceği, okul müdürlerinin müzakere becerilerini geliştirmeleri gerektiği sonucuna varmıştır. Erkuş ve Tabak'a (2008:398) göre iş yaşamında pek çok yönetici müzakere konusunda gerekli eğitimler almadığı için müzakere yeteneklerinin farkına varamamaktadır. Dolayısıyla okul yöneticilerinin müzakere becerileri konusunda bilinçlendirilmesi, müzakere sürecinde sergilemiş oldukları beceri ve davranışların öğretmen algılarına göre incelenmesi gerekli görülmektedir.

Örgüt yöneticileri, çalışanları yönetip yönlendirirken etkileme davranışları sergileyerek gerçekleştirmektedir (Bass, 1985'den Akt.: Güney, 2016:10). Etkileme, zorlama veya konumdan kaynaklanan gücü kullanmadan, karşı tarafın kendi çıkarlarını gözetmesine olanak tanıyarak, tutum ve davranışlarını değiştirme yeteneği olarak tanımlanmaktadır (Huczynski, 1996'dan Akt.: İspir, 2008:2). Taşçı ve Eroğlu'na (2007:534) göre örgütte aşağıdan yukarıya doğru etkilemede başarılı olanlar destekleyici bilgi ve belge kullanmakta, yukarıdan aşağıya doğru etkilemede başarılı olanlar ise çalışanların his ve davranışları üzerinde odaklanmaktadır. O halde okul yöneticileri müzakerede kendi his ve davranışlarını kullanarak astlarının kendi çıkarlarını gözetmesine olanak tanıyıp onları etkileyerek yönlendirebilir. Okul yöneticilerinin öğretmenlere bir görevi yerine getirmelerine yönelik sergiledikleri etkileme davranışlarının müzakere sürecini ne düzeyde yordadığını araştırmak önemli bir hal almıştır.

\section{KURAMSAL ÇERÇEVE}

Müzakere, toplumsal davranışları uyumlu hale getiren bir araç şeklinde düşünülebilir. Bu nedenle okul yöneticilerinin müzakere becerileri ve bu becerilere etki edebilecek davranışların incelenmesi önemsenmektedir. Örtgütsel yapılar, belirli mekanizmalar aracılığıyla iş bölümü, kurallar ve politikalar neticesinde gerçekleştirilir (Cemaloğlu ve Şahin, 2017:9). Okul, toplumsal bir örgüt olarak değerlendirildiğinde örgüt içinde ve dişında, zaman zaman bu mekanizmalarda birtakım problemlerin yaşanması muhtemeldir. Simmel'e (1896) göre uyum, bir toplulukta yetki sahibi olan ile iş görenler arasında gerçekleşen ilişkileri etkileyen başlıca faktörlerdendir. Endüstri alanında işçi - işveren arasındaki problemleri çözmek üzere kullanılan müzakere yöntemlerinin son zamanlarda yönetim alanlarında da dikkat çektiği görülmektedir (Thomas, 1992; Luthans, 1995'den Akt.: Artan, 2002:232). Bu bağlamda okul yöneticilerinin kendilerine tanınan yetkileri kullanarak kurumda bir uyum oluşturması beklenmektedir. Erdoğan'a (2006:153) göre okulda uyum sorunu yaşayan yöneticiler, sorunu eldeki prosedürlerle çözemediği zaman karizmasını ortaya koyarak mevcut politikaların ve prosedürlerin üstüne çıkıp sorunu çözmeye çalışmalıdır. Okul yöneticilerinin kendilerinden beklenilen birçok yeterlilik arasında müzakereci rolü, becerikli bir kamu görevlisi için gerekli görülmektedir (Peters, 2009'dan Akt.: Yalçın vd., 2020:241).

Müzakere kavramıyla ilgili alan yazında farklı tanımlama ve açıklamalar bulunmaktadır. Carnevale ve Pruitt'e (1992:532) göre müzakere, karşıt görüşlerin mücadele ederek çözümlenme sürecidir. Bir örgütte birbirlerine karşı1t görüşlü gibi görünen bireyler yürüttükleri faaliyetlerle birbirlerini tamamlamaktadır (Uçan, 2014:382). Bireyler arası iletişim kopukluğu veya müzakere eksikliği karşıt görüş algısını daha da derinleştirebilir. Özgan vd.'ne (2010:97) göre eğitim kurumlarında güven ortamının oluşması ve karşıt görüşlerin adil ortamda uzlaştırılması okul yöneticilerinin müzakere becerileriyle sağlanabilmektedir. Müzakere süreci, dinamik ve değişim barındıran konuları kapsamaktadır (Erkuş ve Tabak, 2008:399). Bu yüzden okullarda yürütülen müzakereler, amaçlı olmalı ve okul gelişimine katkı sunmalıdır. Örgütlerde bazen amacına uygun olmayan fakat 
müzakere olarak nitelendirilen çeşitli uygulamalara rastlamak mümkündür (Yıldırım vd., 2013:2279). Bu tip uygulamalar okul müdürlerinin müzakereci bir kimliğe sahip olması, müzakere sürecini belli bir yaklaşımla ele alması gerektiğini göstermektedir. Müzakereci bir okul yöneticisi, sürece çözüm önerileri sunma, süreçte taktik geliştirme, karşılıklı taviz alıp verme, ortak karar alma veya gerektiğinde müzakereden çekilme gibi taktikler geliştirebilir. Okul yöneticilerinin başvuracağı taktikler bir müzakere yaklaşımı içinde süreci başarıya ulaştırabilmektedir. Müzakere yaklaşımları şu şekilde açıklanabilir (Ateş, 2020:115-120).

Yumuşak Müzakere Yaklaşımı: Yumuşak müzakere yaklaşımı, karşı tarafı bir rakip olarak görmemekle birlikte ortak menfaatler üzerinde odaklanmaktadır. Yumuşak müzakere yaklaşımında taraflar gereğinden fazla birbirlerine güven duyduklarından dolayı kendi önerilerini kolay bir şekilde geri çekebilmektedir. $\mathrm{Bu}$ durum problemin çözümüne yönelik farklı fikirlerin ortaya çıkmasını engelleyebilmektedir.

Sert Müzakere Yaklaşımı: Sert müzakere yaklaşımında kazan kaybet anlayışı hâkimdir. Otorite ve güç unsurlarını elinde bulunduran taraflar, müzakerede önemli ölçüde avantaj sağlayabilmektedir. Yaklaşımın sağlayacağı avantajların yanında, yıkıcı ve dağıtıcı yansımaları da bulunmaktadır.

Prensipli Müzakere Yaklaşımı: Prensipli müzakere yaklaşımı, sert müzakere yaklaşımıyla yumuşak müzakere yaklaşımının olumlu taraflarının esas alındığı, müzakere sürecinde her iki yaklaşımın da eksik kalan taraflarının giderildiği yaklaşım olarak tanımlanmaktadır.

Ade vd. (2018:5) yaptıkları araştırmada, müzakerede beceri ve bilgi öğretiminin yeterli olmadığı, insanların müzakerelere yaklaştığı psikolojik yönelimlerin, müzakere sonucuna etki edebileceğini savunmuşlardır. O halde okul yöneticileri, psikolojik yönelimler üzerinden çalışanlarını yaptıkları müzakerelerle etkileyebilir. Güney’e (2016:23) göre çalışanın kuruma olan bağl1lığı yöneticiye olan bağlılı̆̆1 üzerinden gerçekleşmektedir. Yöneticilerin çalışanları tesir altına alma kabiliyeti pek çok davranış bilimcinin ilgisini çekmektedir. Hangi etkileme taktiğinin en iyi işlev gördügüne dair tespitte bulunmak oldukça güçtür (Yaylacı, 2006:95). Bu yüzden müzakereci bir okul yöneticisi, müzakere sürecinde, duruma göre etkileme taktiğine başvurması sürece olumlu katk1 sağlayabilir.

Etkileme davranışlarına, Bass'ın (1960) iki faktörlü taksonomisi ile French ve Revan'ın (1959) güç taksonomisi çalışmalarının temel oluşturduğu düşünülmektedir (Kuru Çetin, 2013:35). Bu yıllardan sonra pek çok araştırma (Kipnis vd., 1980; Yukl vd., 1992; Ralston vd., 1993; Steizel ve Rimbau Gilabert, 2013) yapılmıştır (Ünal ve Özaslan, 2017:178). Alan yazında genel olarak sert etkileme taktikleri (güç, otorite, baskı) ve 1lıman etkileme taktikleri (akll yoluyla ikna etme, bilgilendirme, iş birliği, kişisel yakınlık kullanma, teşvik edici talepte bulunma, istişarede bulunma, takdir etme) olarak kategorize edilmektedir (Dağlı ve Çalık, 2016:33). Her iki etkileme taktiğini içine alan proaktif etkileme davranışlarını Yukl (2013:201-206) şu şekilde açıklamaktadır;

Akıl yoluyla ikna etme: Rasyonel ikna olarak da ifade edilen bu etki taktikte mantıksal argümanlar kullanılarak karşı tarafı etkilemeye çalışılmaktadır. Bir talebin veya teklifin neden kuruma yarar sağlayacağına yönelikçalışanların yöneticiler tarafından ikna edilmeleri gerekmektedir. Yöneticilerin uzmanlık veya güvenirliğe sahip olması bu taktiği daha da uygulanabilir hale getirebilmektedir.

Karşılık verme: Astların kurumda bir fedakârlık yapmaları durumunda, yöneticiler tarafından onlara fedakârlık gösterileceğinin hissettirilmesi şeklinde ifade edilmektedir. Astlardan ziyade yöneticilerin başvurduğu bu taktikte astlara sunulan vaadin gerçekçi ve uygulanabilir olması astları daha da motive edebilir. Astların yöneticiye yapacakları iyilik, astları için bir anlam ifade etmeyebilir fakat karşıllı̆ında kendilerine yapılacak iyilik, onlar için cezbedici olabilir. Ücret artışı, terfi ve ödül gibi vaatler örnek olarak verilebilir.

Teşvik edici talepte bulunma: İlham verici temyizler olarak da tanımlanabilir. Astların bağlılığını kazanmak için başvurulan bu taktikte yöneticilerin astların duygularına hitap ederek, onların değer yargılarından faydalanarak verilen görevin yerine getirilmesinde onları isteklendirmesi şeklinde ifade edilmektedir. Bu bağlamda yöneticinin astlarını iyi tanıması, onların iç dünyalarını keşfetmesi gerekebilir.

Kurallara uygunluk: Meşrulaştırma olarak da ifade edilmektedir. Yöneticiler, kurumun sahip olduğu sözleşmeler ve kurallar dizini doğrultusunda astlarına bir görevi yaptırma eylemi olarak ifade edilebilir. Astların kendilerine verilen görevin yasal çerçevesi hakkında bilgi sahibi olmadığı durumlarda bu taktik kullanılabilir.

Bilgilendirme: Yöneticinin astlarına talebin gerçekleşmesi durumunda sağlanacak faydalar hakkında bilgi vermesi şeklinde tanımlanmaktadır. Burada sağlanacak faydalar kuruma değil, kişiye dönük şeklinde 
gerçekleşmektedir. Kişinin kariyer, iş tatmini veya iş tazminatı şeklinde düşünülebilir. Bu taktiğin yöneticiden ziyade çalışanlar üzerinde uygulanması yararlı görülmektedir.

Baskı: Yöneticilerin iş ortamında astlarına verdikleri direktiflerin yerine getirilip getirilmediğini öğrenmek için astlarını kontrol etme, uyarılarda bulunma, tehdit etme gibi uyguladıkları taktikler şeklinde tanımlanmaktadır. Bu taktik çalışanlarda yöneticilere karşı olumsuz bir tutum bırakabilir.

İ̧ birliği yapma: Yöneticinin bir öneriyi veya bir görevi astlarına sunarken, astlara kolaylık sağlayacak ortamlar oluşturması, onlara yol göstermesi ve ortak çalışma alanları oluşturması şeklinde ifade edilmektedir.

Takdir etme: Bu taktik yaranma olarak da açıklanmaktadır. Yöneticinin bir işi, iş görene yaptırırken ona iltifat etme, onun başarılarından söz etmek gibi davranışlar sergilemesi bu taktiğin gereği olarak ifade edilmektedir. Takdir etmenin bireyde etki bırakabilmesi övgüyü veya iltifatı yapan kişinin o alanda yüksek statüye veya uzman olması ile orantılı sayılmaktadır.

İstişarede bulunma: $\mathrm{Bu}$ taktiğin bir diğer adı danışmadır. Genellikle bir görevin nasıl yerine getirilmesiyle ilgili astlar üstlerle istişarede bulunur. Ancak kurumda alınmış bir kararın veya kurumun hedeflediği herhangi bir durumun üstler, astlarla bir araya gelerek kararın gerçekleştirilmesinde izlenecek yolun istişare edilmesi şeklinde de gerçekleştirilebilmektedir. Karar aşamasında astlara söz hakkı tanınması, yürütülecek faaliyette astların daha özverili davranış sergilemelerine olanak tanıyabilir.

Kişisel yakınlığ kullanma: Kişilerin dostluklarını, arkadaşlıklarını kullanarak karşı taraftan kendilerine iyilik yapılmasını istemeleridir. Yöneticilerinin aslarına kullanmaları çok nadir görülse de aynı görev pozisyondaki kişilerin bunu kullanma sıklıkları yüksektir.

Başkalarıyla koalisyon kurma: Bu taktik, kişilerin karşı tarafı işe koşmak için başkalarından destek istemesi olarak tanımlanmaktadır. Cialdini'na (2001:192) göre toplumsal kanıt ilkesinde insanlar, karar alırken çoğu zaman çevresindeki kişilerin kararlarına bakarak karar vermektedir. Dolayısıyla neyin doğru neyin yanlış olduğuna başkalarının yaptıklarına bakarak anlam vermektedir. Genellikle yöneticiler kendi fikirlerini bir üst yönetime kabul ettirmek için kullanır. Nadir olarak görülse de yöneticiler astlarını işe koşarken bu taktiği kullanabilirler (Yukl, 2013:206).

Etkileme davranışları, müzakere sürecinde doğru yerde ve doğru zamanda sergilenirse müzakereciye önemli avantajlar sağlayabilir. Araştırma, kurum yöneticileri ile çalışanlar arasında yapılan müzakerelerde etkileme davranışlarının yordayıcılığı üzerinde durmaktadır.

\section{ARAŞTIRMANIN ÖNEMI VE AMACI}

$\mathrm{Bu}$ çalışma, öğretmen algılarına göre okul yöneticilerinin müzakere becerilerinin yordayıcısı olarak etkileme davranışlarını belirlemeyi amaçlamaktadır. Ayrıca araştırma, öğretmen algılarına göre okul yöneticilerinin etkileme davranışları ile müzakere becerileri arasındaki ilişkiyi ortaya çıkarmayı amaçlamaktadır. Araştırma, öğretmen algılarına göre okul yöneticilerinin müzakere becerilerinin öğretmenlerin cinsiyet, kıdem, okul türü ve öğrenim durumu değişkenine göre farklılaşıp farklılaşmadığını test etmesi bakımından önemsenmektedir. Araştırmanın amacına hizmet etmek üzere alt amaçlar belirlenmiştir. Bu amaç kapsamında aşağıdaki sorulara cevap aranacaktır;

3.1. Öğretmen algılarına göre okul yöneticilerinin müzakere becerileri alt boyut puan ortalamalar1; Öğretmenlerin cinsiyet, kıdem, çalıştığı okul türü ve öğrenim durumu değişkenine göre farklılık göstermekte midir?

3.2. Öğretmenlerin algılarına göre okul yöneticilerinin öğretmenleri etkileme davranışları ile müzakere becerileri arasında bir ilişki var mıdır?

3.3. Öğretmen algılarına göre okul yöneticilerinin etkileme davranışları, okul yöneticilerinin müzakere becerilerileri alt boyutlarının bir yordayıcısı mıdır? 


\section{ARAŞTIRMANIN METODOLOJISI}

Araştırma, nedensel karşılaştırma ve ilişkisel tarama modelinde olup, nicel bir araştırmadır. "İnsan grupları arasındaki farklılıkların nedenlerini ve sonuçlarını koşullar ve katılımcılar üzerinde herhangi bir müdahale olmaksızın belirlemeyi amaçlayan çalışmalara nedensel karşılaştırma (causal-comparative) araştırması denir" (Büyüköztürk vd., 2016:16). İlişkisel tarama modelinde ise iki ya da daha fazla değişken arasında birlikte belirlemeyi amaçlayan araştırma modelidir (Karasar, 2016:114). Araştırma, bir bağımsız ve bir bağımlı değişken olmak üzere iki değişkenden oluşmaktadır. Okul yöneticilerinin etkileme davranışları bağımsız değişken, okul yöneticilerinin müzakere becerileri ise bağımlı değişkeni oluşturmaktadır. Ayrıca öğretmenlerin demografik özelliklerinden (cinsiyet durumu, okul türü durumu, kldem durumu ve ögrenim durumu) elde edilen veriler bağımsız değişken olarak kabul edilmiştir.

\subsection{Evren- Örneklem}

Araştırmanın evreni 2019 - 2020 Eğitim- Öğretim yılında Türkiye'nin İç Anadolu Bölgesinde bulunan Konya Büyükşehir Merkez ilçelerine bağlı resmi okullarda görev yapan öğretmenlerden oluşmaktadır. Araştırmanın örneklemi, kademeli örnekleme yöntemi ile oluşturulmuştur. İlk önce kamuya ait okul türlerindeki okulları kapsayacak şekilde, büyükşehir merkezinde bulunan toplam okul sayıları tespit edilmiştir. Tespit edilen okullar birinci aşamada okul türüne göre tabakalara ayırılmıştır. Her tabakadaki okullar küme olarak kabul edilmiştir. Tabakalardan rastgele kümeleme yöntemi ile okullar seçilmiştir. Seçilen okullara gidilerek envanter uygulanmıştır. Tablo.1'de görüldüğü üzere evrende bulunan 15.323 öğretmen, birinci aşamada anaokulu, ilkokul, ortaokul ve lise olmak üzere dört tabakaya ayırılmıştır. Öğretmenlerin görev yaptıkları okul türünde bulunan öğretmen sayısı tespit edilmiştir. İkinci aşamada evrende bulunan tüm okul türlerinin sayısı tespit edilmiştir. Okul türlerine göre ortalama her bir kümede yer alan öğretmen sayısı hesaplanmıştır. Son olarak rastgele kümeleme yöntemiyle okullara gidilerek ölçme aracı uygulanmıştır. Böylece evrenin tüm alt birimleri belirlenip, evrendeki büyüklük oranlarıyla orantılı olacak şekilde tabakalar oluşturulmuş ve tabakalardan küme okullar belirlenerek alt grupların temsil edilmeleri sağlanmıştır.

Tablo 1. Aşamalı Örnekleme Yöntemiyle İlgili İstatistiki Veriler

\begin{tabular}{|c|c|c|c|c|}
\hline \multicolumn{5}{|c|}{ Tabaka } \\
\hline Evren & Anaokulu & İkokul & Ortaokul & Lise \\
\hline $\mathbf{1 5 . 3 2 3}$ & $1348(\% 8,8)$ & $5148(\% 33,6)$ & $3996(\% 26)$ & $4857(\% 31,7)$ \\
\hline $\mathbf{7 3 6}$ & 65 & 247 & 191 & 233 \\
\hline $\mathbf{3 7 4}$ & 33 & 125 & 97 & 118 \\
\hline \multicolumn{7}{|c|}{ Kümeleme } & 142 & 89 \\
\hline $\begin{array}{c}\text { Ortalama küme birimindeki öğretmen } \\
\text { sayısı }\end{array}$ & 47 & 166 & 28 & 55 \\
\hline Rasgele kümeleme & 29 & 31 & 7 & 5 \\
\hline
\end{tabular}

Tablo 1'den anlaşılacağı üzere anaokulda 1348 öğretmen, ilkokulda 5148, ortaokulda 3996 ve lisede 4857 öğretmen görev yapmaktadır. Aypay (2015:175), bir örneklemde bulunması gereken katılımcı sayısını ortalama bir değer üzerinden \%3 hata payı ile 10.000 - 20.000 evren büyüklüğüne 370-377 katılımcının yeterli olduğunu ön görmektedir. Araştırma grubunda anaokulundan 65, ilkokuldan 247, ortaokuldan 191 ve liseden 233 öğretmen olmak üzere 736 katılımcı bulunmaktadır. Katılımcı sayısının yeterli olduğu görülmektedir. Araştırma grubunda yer alan katılımc1larla ilgili veriler Tablo.2'de yer almaktadır. 
Tablo 2. Araştırma Grubu ile İlgili İstatistiki Veriler

\begin{tabular}{|c|c|c|}
\hline Cinsiyet & Frekans(f) & Yüzde (\%) \\
\hline Kadın & 434 & 59 \\
\hline Erkek & 302 & 41 \\
\hline Kıdem & & \\
\hline 1-5 Y11 Aras1 & 106 & 14,4 \\
\hline 6-10 Y1l Aras1 & 133 & 18,1 \\
\hline 11-15 Yı1 Aras1 & 172 & 23,4 \\
\hline 16 ve Üstü & 325 & 44,1 \\
\hline Öğrenim Durumu & & \\
\hline Lisans & 624 & 84,8 \\
\hline Lisansüstü & 112 & 15,2 \\
\hline
\end{tabular}

Tablo 2 incelendiğinde araştırmaya katılan öğretmenlerin \%59'u (434) kadın; \%41'i (302) ise erkek öğretmenlerden oluşmaktadır. Araştırmaya katılan kadın öğretmenlerin yüzdesnin erkek öğretmenlerin yüzdesinden yüksek olduğu görülmektedir. Öğretmenler, kıdem durumuna göre incelendiğinde \%14,4'ü (106) 1-5 y1l arası; \%18,1'i (133) 6-10 yıl aras1; \%23,4'ü (172) 11-15 y1l arası; \%44,1'si (325) 16 ve üzeri y1l arası kıdeme sahip öğretmenler olduğu görülmektedir. 16 ve üstü yıl arası kıdeme sahip katılımcıların toplam katılımcıların yarısına yakın olduğu gözlemlenmiştir. Araştırmaya katılan öğretmenlerin öğrenim durumuna göre \%84,8 si (624) lisans; \%15,2 si (112) lisansüstü eğitim durumuna sahip olduğu görülmektedir. Genel olarak katılımcıların öğrenim durumları incelendiğinde katılımcıların çoğunun lisans öğrenim durumuna sahip olduğu görülmektedir.

\subsection{Verilerin Toplanması}

Araştırmanın verileri Türkiye'de İç Anadolu Bölgesinde yer alan Konya Büyükşehir merkez ilçelerinde (Karatay-Selçuklu-Meram) yer alan kamu okullarından elde edilmiştir. Evrende bulunan tüm okullar, okul türlerine göre tabakalara ayırılmıştır. Tabakalara ayrılan okullar numaralandırılarak oranlama yöntemi küme okullar oluşturulmuştur. Küme okullardan rastgele öğretmen seçilerek veri toplama aracı uygulanmıştır. Veri toplama araçları hakkında ayrıntılı bilgi katılımcılara verilmiştir. Araştırmada, gönüllülük esasına dayanılarak rahat bir ortam oluşturulmuştur.

\subsection{Veri Toplama Araçları}

Araştırmada öğretmenlerin demografik özelliklerinin yer aldığı "Kişisel Bilgi Formu”, "Müzakere Becerileri Ölçeği" ve "Etkileme Davranışları Ölçeği”" veri toplama aracı olarak kullanılmıştır. Ölçeklerin araştırmada kullanılabilmesi için gerekli izinler alınmıştır.

4.3.1. Etkileme Davranışı Ölçeği: Etkileme davranışları ölçeği, Yukl ve Falbe (1990) tarafından geliştirilmiş Gözü (2012) tarafından Türkçeye uyarlanmıştır. Ölçek, Türkçeye uyarlanırken önce Türkçeye çevrilip ardından tekrar İngilizceye çevrilerek kültürel farklılıktan dolayı bazı ifadeler değiştirilmiş ve ABD'de ölçeğin iç tutarlık kat sayıs1 0,83; Türkiye'de 0,92 bulunmuştur (Gözü, 2012). Etkileme davranış ölçeği, 11 etkileme davranışını 4'er madde halinde toplamda 44 maddeyle Etkileme davranışı ölçmektedir. Ölçek, Doğrulayıcı faktör analizine göre GFI=.90; CFI=94; RMSEA= 0,05 olarak hesaplanmıştır (Yukl vd., 2008). Ölçek maddelleri beşli likert tipi ölçek şeklinde hazırlanmıştır. Buna göre ölçekte yer alan maddeler sırasıyla "Hiç kullandığını hatırlamıyorum", "Çok nadir kullanır", "Zaman zaman kullanır", "Sık kullanır" ve "Çok sık kullanır" şeklinde ifade edilmiştir. Ölçeğin güvenirliğini test etmek üzere araştırmaya katılan katılımcılardan elde edilen verilere göre ölçeğin güvenirliğine yönelik yapılan iç tutarlılık kat sayısı (Cronbach Alpha), etkileme davranışları ölçeğinin alt boyutlarından akıl yoluyla ikna etme 0,88 ; karş1lık verme 0,91 ; teşvik edici talepte bulunma 0,89 ; kurallara uygunluk 0,89 ; bilgilendirme 0,91 ; bask1 yapma 0,85 ; iş birliği yapma 0,91 ; takdir etme 0,93 ; istişarede 
bulunma 0,92; kişisel yakınlığı kullanma 0,91; başkalarıyla koalisyon kurma 0,87 olarak hesaplanmıştır. Ölçek genelinde ise iç tutarlılık kat sayısı 0,94 (Cronbach Alpha) olarak tespit edilmiştir. Dolayısıyla ölçeğin güvenilir olduğu sonucuna varılmıştır.

4.3.2. Müzakere Becerileri Ölçeği: okul yöneticilerinin müzakere becerilerini belirlemeye yönelik Özgan, Çelik ve Bozbayındır (2011) tarafından geliştirilen "Müzakere Becerileri Ölçeği” kullanılmıştır. Ölçek, doğrulayıcı faktör analizine göre uyum değerlerinin indeksleri, RMSEA=0,074; $\mathrm{NFI}=0,98 ; \mathrm{CFI}=0,99$; IFI= 0,99; RFI= 0,97 ve SRMR= 0,035 değerlerine sahiptir (Özgan vd., 2011:70). Ölçekte yer alan 1, 2, 3, 4, 5, 6, 7, $8,9,10,11,12,13$ ve 14 maddeler güven ortamı oluşturma alt boyutunu ölçen maddeler olarak belirlenmiştir. Ölçekte yer alan $15,16,17,18,19,20,21,22$ ve 23 maddeler ise çözümden yana olma alt boyutunu ölçen maddeler olarak belirlenmiştir (Özgan vd., 2011:72). Ölçeğin güvenirlik katsayısı incelendiğinde ölçek genelinde 0,98; güven ortamı oluşturma alt boyutunda 0,96; çözümden yana olma alt boyutunda 0,94 Cronbach Alpha olarak bulunmuştur (Özgan vd., 2011:74). Ayrıca ölçeğin güvenirliğini test etmek üzere araştırmaya katılan katılımcılar üzerinde yapılan hesaplamada iç tutarlılık kat sayısı (Cronbach Alpha) 0,95 olarak hesaplanmıştır. Ölçeğin alt boyutlarının güvenirliğini belirlemek üzere hesaplanan iç tutarlılık kat sayıları (Cronbach Alpha) sırasıyla, güven ortamı oluşturma alt boyutunda 0,92; çözümden yana olma alt boyutunda 0,93 olarak tespit edilmiştir. Ölçeğin varyans değeri \%70,69 olduğu, ölçek maddellerinin ayırt edicilik güçleri $\% 27$ alt ve üst maddeler arasında tüm maddelerin ayırt edici olduğu sonucuna varılmışırı (Özgan vd., 2011:75). $\mathrm{Bu}$ verilerden yola çıkarak ölçeğin güvenilir ve geçerli olduğu söylenebilir.

\subsection{Verilerin Analizi}

Araştırmada kullanılan anket formunda katılımcıların normal dağılım gösterip göstermediğini belirlemek üzere normallik testi uygulanmıştır. Normallik testinde verilerin betimsel istatistikleri (ortalama, standart sapma, basıklık ve çarpıklık katsayıları) hesaplanmıştır.

Tablo 3. Normallik Değerleriyle İlgili İstatistiki Veriler

\begin{tabular}{|c|c|c|c|c|c|c|}
\hline Ölçek Adı & Değişken & $\begin{array}{c}\text { Aritmetik } \\
\text { Ort. }\end{array}$ & Medyan & Mod & $\begin{array}{c}\text { Çarpıklık } \\
\text { Katsayısı }\end{array}$ & $\begin{array}{c}\text { Basıklık } \\
\text { Katsayısı }\end{array}$ \\
\hline Toplam Puan Ort. & Her İki Ölçek & 3,12 & 3,08 & 3,69 & $-0,10$ & $-0,05$ \\
\hline Etkileme Dav. & Puan ort. & 2,95 & 2,95 & 3,18 & $-0,03$ & $-0,05$ \\
\hline Müzakere Bec. & Puan ort. & 3,45 & 3,47 & 3,22 & $-0,31$ & $-0,14$ \\
\hline
\end{tabular}

Tablo 3’te görüldüğü üzere değişkenlere ilişkin hesaplanan çarpıklık ve basıklık değeri her iki boyutta da -1 ve +1 aralığında hesaplanmıştır. Aritmetik ortalama, medyan ve modun birbirine yakın değerler aldığı gözlemlenmektedir. İdeal olan dağılım, çarpıklık değerlerinin sıfır olduğu, arirmetik ortalama, medyan ve mod un birbirine eşit veya yakın değerlere sahip olan dağılımdır (Can, 2018:45). Dolayısıyla araştırma, normal dağ $11 \mathrm{~m}$ gösterdiğinden verilerin analizinde parametrik testler kullanılmıştır. Elde edilen bulgular sonucunda iki kategorik parametrik testlerde t-testi; ikiden fazla kategorik parametrik testlerde ise tek yönlü varyans analizi kullanılmıştır. Araştırmada iki değişken (bağımlı - bağımsız) arasındaki ilişkiyi belirlemek üzere Pearson Korelasyon Analizi yapılmıştır. Ayrıca bağımsız değişkenin bağımlı değişkeni ne düzeyde etkilediğini belirlemek üzere regresyon analizi yapılmıştır.

\section{ARAŞTIRMANIN BULGULARI}

Öğretmen algılarına göre okul yöneticilerinin müzakere becerileri, öğretmenlerin demografik özelliklerine (cinsiyet durumu, çalıştıkları okul türü, kıdem durumu ve ögrenim durumlarına) göre değerlendirilmiştir. Öğretmen algılarına göre okul yöneticilerinin müzakere becerileri, güven ortamı oluşturma ve çözümden yana olma alt boyutları olmak üzere iki farklı boyutta sergilenebilmektedir.

Tablo 4. Katılımcıların Cinsiyet Durumuna Göre Okul Yöneticilerinin Müzakere Becerileri

\begin{tabular}{|c|c|c|c|c|c|c|}
\hline DEĞIŞKEN & Cinsiyet Durumu & $\mathbf{N}$ & $\bar{X}$ & ss & t & p \\
\hline \multirow{2}{*}{ Güven Ortamı Oluşturma } & Kardın & 434 & 49,4 & 11,3 & \multirow{2}{*}{2,25} & \multirow{2}{*}{0,024} \\
\cline { 2 - 5 } & Erkek & 302 & 47,5 & 10,6 & & \\
\hline \multirow{2}{*}{ Çözümden Yana Olma } & Kadın & 434 & 31,9 & 7,62 & \multirow{2}{*}{$-2,54$} & \multirow{2}{*}{0,011} \\
\cline { 2 - 5 } & Erkek & 302 & 30,5 & 7,07 & & \\
\hline
\end{tabular}


Tablo 4 incelendiğinde elde edilen puanların öğretmenlerin cinsiyet değişkenine göre okul yöneticilerinin müzakere becerileri alt boyutlarından güven ortamı oluşturma puan ortalaması ve bu puan ortalamaları arasında farklılaşmanın olup olmadığına ilişkin bağımsız t-testi bulguları bulunmaktadır. Bu bulgulara baktığımızda kadın öğretmenlerin algılarına göre okul yöneticilerinin güven ortamı oluşturma puan ortalaması 49,4; Erkek öğretmenlerin algılarına göre okul yöneticilerinin güven ortamı oluşturma puan ortalaması ise 47,5 olarak bulgulanmıştır. Erkek ve kadın öğretmenlerin algılarına göre okul yöneticilerinin müzakere becerileri alt boyutlarından güven ortamı oluşturma puan ortalamaları arasındaki t değeri $-2,25$ olarak hesaplanmıştır. Tablo.4'deki veriler incelendiğinde öğretmen algılarına göre okul yöneticilerinin güven ortamı oluşturma puan ortalamaları öğretmenlerin cinsiyet değişkenine göre anlamlı bir farkl1lık göstermektedir $(p<0,05)$. Öğretmen algılarına göre okul yöneticilerinin müzakere becerileri alt boyutlarından güven ortamı oluşturma puan ortalamaları incelendiğinde kadın öğretmenlerde oluşan puan ortamasının erkek öğretmenlerde oluşan puan ortalamasından yüksek olduğu görülmektedir. Öğretmenlerin cinsiyet değişkenine göre okul yöneticilerinin müzakere becerileri alt boyutlarından çözümden yana olma puan ortalaması ve bu puan ortalamaları arasında farklılaşmanın olup olmadığına ilişkin bağımsız t-testi bulguları bulunmaktadır. Bu bulgular incelendiğinde, kadın öğretmenlerin algılarına göre okul yöneticilerinin müzakere becerileri alt boyutlarından çözümden yana olma puan ortalaması 31,9; erkek öğretmenlerin algılarına göre okul yöneticilerinin müzakere becerileri alt boyutlarından çözümden yana olma puan ortalaması ise 30,5 olarak hesaplanmıştır. Erkek ve kadın öğretmenlerin algılarına göre okul yöneticilerinin müzakere becerileri alt boyutlarından çözümden yana olma puan ortalamaları arasındaki t değeri -2,54 olarak hesaplanmıştır. Tablo 4'deki veriler incelendiğinde öğretmen algılarına göre okul yöneticilerinin müzakere becerileri alt boyutlarından çözümden yana olma puan ortalamaları arasında öğretmenlerin cinsiyet değişkenine göre anlamlı bir farklılık görülmektedir $(\mathrm{p}<0,05)$. Öğretmen algılarına göre okul yöneticilerinin müzakere becerileri alt boyutlarından çözümden yana olma puan ortalamaları incelendiğinde kadın öğretmenlerde oluşan puan ortalamalarının erkek öğretmenlerde oluşan puan ortalamalarınkinden yüksek olduğu gözlemlenmektedir.

Tablo 5. Katılımcıların Çalıştığı Okul Türü Durumuna Göre Okul Yöneticilerinin Müzakere Becerileri

\begin{tabular}{|c|c|c|c|c|c|c|c|}
\hline DEĞİŞKEN & $\begin{array}{c}\text { Okul Türü } \\
\text { Durumu }\end{array}$ & $\mathbf{N}$ & $\bar{X}$ & ss & $\mathbf{F}$ & $\mathbf{p}$ & $\begin{array}{c}\text { Gruplar } \\
\text { Arası }\end{array}$ \\
\hline \multirow{4}{*}{$\begin{array}{l}\text { Güven Ortamı } \\
\text { Oluşturma }\end{array}$} & 1. Ana okul & 65 & 50,6 & 10,8 & \multirow{4}{*}{3,41} & \multirow{4}{*}{0,01} & \multirow{4}{*}{$\begin{array}{l}1>2 \\
2>3 \\
3>4\end{array}$} \\
\hline & 2. İlkokul & 247 & 49,4 & 11,0 & & & \\
\hline & 3. Ortaokul & 191 & 47,7 & 10,8 & & & \\
\hline & 4. Lise & 233 & 46,8 & 11,2 & & & \\
\hline \multirow{4}{*}{$\begin{array}{c}\text { Çözümden Yana } \\
\text { Olma }\end{array}$} & 1. Ana okul & 65 & 32,0 & 7,45 & \multirow{4}{*}{3,00} & \multirow{4}{*}{0,03} & \multirow{4}{*}{$\begin{array}{l}1>3 \\
1>4 \\
2>3 \\
2>4\end{array}$} \\
\hline & 2. İlkokul & 247 & 32,1 & 7,42 & & & \\
\hline & 3. Ortaokul & 191 & 30,4 & 7,18 & & & \\
\hline & 4. Lise & 233 & 30,4 & 7,53 & & & \\
\hline
\end{tabular}

Tablo 5'de görüldüğü üzere öğretmen algılarına göre okul yöneticilerinin müzakere becerileri alt boyutlarından güven ortamı oluşturma puan ortalamaları anaokul 50,6; ilkokul 49,4; ortaokul 47,7 ve lisede 46,8 olarak gözlemlenmiştir. Puan ortalamalarına ilişkin $F$ değeri 3,41 olarak hesaplanmıştır. Elde edilen $F$ değeri dikkate alındığında öğretmenlerin çalıştığı okul türü değişkenine göre okul yöneticilerinin müzakere becerileri alt boyutlarından güven ortamı oluşturma puan ortalamalarının anlamlı bir şekilde farklılaştğı görülmektedir $(\mathrm{p}<0,05)$. Bu farklılaşmanın kaynağını belirlemek üzere yapılan ikili karşılaştırmada anaokulda çalışan öğretmenlerin okul yöneticilerinin müzakere becerileri alt boyutlarından güven ortamı oluşturmada oluşan puan ortalamalarının sırasıyla ilkokul, ortaokul ve lisede çalışan öğretmenlerde oluşan puan ortalamalarından yüksek olduğu görülmektedir. İlkokulda çalışan öğretmenlerde oluşan puan ortalamalarının ortaokul ve lisede çalışan öğretmenlerde oluşan puan ortalamalarından yüksek olduğu tespit edilmiştir. Ortaokulda çalışan öğretmenlerde oluşan puan ortalamalarının da lisede çalışan öğretmenlerde oluşan puan ortalamalarından yüksek olduğu görülmektedir. Öğretmen algılarına göre okul yöneticilerinin müzakere becerileri alt boyutlarından çözümden yana olma alt boyutu puan ortalamaları Tablo 5'ten anlaşılacağı gibi anaokul 32,0; ilkokul 32,1; ortaokul 30,4 ve lisede 30,4 olarak gözlemlenmiştir. Puan ortalamalarına ilişkin F değeri 3,00 olarak hesaplanmıştır. Elde edilen $\mathrm{F}$ değeri dikkate alındığında öğretmenlerin çalıştığı okul türü değişkenine göre okul yöneticilerinin müzakere becerileri alt boyutlarından çözümden yana olma alt boyut puan ortalamaları anlamlı bir şekilde farklılaşma göstermitir $(\mathrm{p}<0,05)$. Bu farklılaşmayı belirlemek üzere yapılan ikili karşılaştırmada, anaokul ve 
IRMAK, Adnan ve YILMAZ, Ercan - Okul Yöneticilerinin Müzakere Becerilerinin Yordayıcısı Olarak Etkileme Davranışları

ilkokulda çalışan öğretmenlerde oluşan puan ortalamalarının ortaokul ve lisede çalışan öğretmenlerde oluşan puan ortalamalarından anlamlı bir şekilde yüksek olduğu gözlemlenmiştir.

Tablo 6. Katılımcıların Kıdem Durumuna Göre Okul Yöneticilerinin Müzakere Becerileri

\begin{tabular}{|c|c|c|c|c|c|c|}
\hline DEĞİŞKEN & Kıdem Durumu & $\mathbf{N}$ & $\bar{X}$ & SS & $\mathbf{F}$ & $\mathbf{p}$ \\
\hline \multirow{4}{*}{ Güven Ortamı Oluşturma } & 1. $1-5 \mathrm{y} 11$ & 106 & 47,9 & 11,2 & \multirow{4}{*}{0,91} & \multirow{4}{*}{0,43} \\
\hline & 2. $6-10 \mathrm{y} 1 \mathrm{l}$ & 133 & 48,9 & 11,4 & & \\
\hline & 3. $11-15 \mathrm{y} 11$ & 172 & 49,2 & 11,7 & & \\
\hline & 4. 16 ve üstü & 325 & 47,6 & 10,5 & & \\
\hline \multirow{4}{*}{ Çözümden Yana Olma } & 1. $1-5 \mathrm{y} 1 \mathrm{l}$ & 106 & 31,1 & 7,64 & \multirow{4}{*}{0,90} & \multirow{4}{*}{0,44} \\
\hline & 2. $6-10 \mathrm{y} 1 \mathrm{l}$ & 133 & 31,0 & 7,10 & & \\
\hline & 3. $11-15 \mathrm{y} 1 \mathrm{l}$ & 172 & 31,9 & 7,83 & & \\
\hline & 4. 16 ve üstü & 325 & 30,7 & 7,27 & & \\
\hline
\end{tabular}

Tablo 6' da görüldüğü üzere öğretmen algılarına göre okul yöneticilerinin müzakere becerileri alt boyutlarından güven ortamı oluşturma puan ortalamaları, öğretmenlerin kıdem durumu değişkenine göre 1-5 yıl kıdeme sahip öğretmenler 47,9; 6-10 yıl kıdeme sahip öğretmenler 48,9; 11-15 y1l kıdeme sahip öğretmenler 49,2; 16 ve üstü yıl kıdeme sahip öğretmenler 47,6 olarak tespit edilmiştir. Puan ortalamalarına ilişkin F değeri 0,91 olarak hesaplanmıştır. Elde edilen $\mathrm{F}$ değeri dikkate alındığında, öğretmen algılarına göre okul yöneticilerinin müzakere becerileri alt boyut puan ortalamaları, öğretmenlerin kıdem durumu değişkenine göre anlamlı bir şekilde farklılaşma göstermemektedir ( $>0,05)$. Tablo 6 incelendiğinde, öğretmen algılarına göre okul yöneticilerinin müzakere becerileri alt boyutlarından çözümden yana olma puan ortalamaları, öğretmenlerin kıdem durumuna göre 1-5 y1l kıdeme sahip öğretmenlerin 31,1; 6-10 y1l kıdeme sahip öğretmenlerin 31,0; 11-15 yıl kıdeme sahip öğretmenlerin 31,9; 16 ve üstü yıl kıdeme sahip öğretmenlerin 30,7 olarak gözlemlenmiştir. Puan ortalamalarına ilişkin F değeri 0,90 olarak hesaplanmıştır. Elde edilen F değeri dikkate alındığında öğretmen algılarına göre okul yöneticilerinin müzakere becerileri alt boyut puan ortalamalarının öğretmenlerin kıdem durumu değişkenine göre anlamlı bir şekilde farklılaşma bulunmamıştır ( $p>0,05)$.

Tablo 7. Katılımcıların Öğrenim Durumuna Göre Okul Yöneticilerinin Müzakere Becerileri

\begin{tabular}{|c|l|c|c|c|c|c|}
\hline DEĞíŞKEN & Öğrenim Durumu & $\mathbf{N}$ & $\bar{X}$ & ss & t & p \\
\hline \multirow{2}{*}{ Güven ortamı oluşturma } & 1. Lisans & 624 & 3,46 & 0,796 & \multirow{2}{*}{0,90} & \multirow{2}{*}{0,36} \\
\cline { 2 - 6 } & 2. Lisansüstü & 112 & 3,38 & 0,779 & & \\
\hline \multirow{2}{*}{ Çözümden Yana Olma } & 3. Lisans & 624 & 3,47 & 0,829 & \multirow{2}{*}{0,97} & \multirow{2}{*}{0,33} \\
\cline { 2 - 6 } & 4. Lisansüstü & 112 & 3,39 & 0,800 & & \\
\hline
\end{tabular}

Tablo 7 incelendiğinde, öğretmen algılarına göre okul yöneticilerinin müzakere becerileri alt boyutlarından güven ortamı oluşturma puan ortalamaları, lisans öğrenim durumlarına sahip öğretmenlerin 3.46; lisansüstü öğrenim durumlarına sahip öğretmenlerin 3,38 olarak gözlemlenmiştir. Puan ortalamalarına ilişkin t değeri 0,90 olarak hesaplanmıştır. Elde edilen $t$ değeri dikkate alındığında öğretmen algılarına göre okul yöneticilerinin müzakere becerileri alt boyutlarından güven ortamı oluşturma puan ortalamalarının öğretmenlerin öğrenim durumu değişkenine göre anlamlı bir şekilde farklılaşma göstermediği görülmektedir ( $p>0,05$ ). Tablo 7'de belirtildiği gibi öğretmen algılarına göre okul yöneticilerinin müzakere becerileri alt boyutlarından çözümden yana olma puan ortalamaları, lisans öğrenim durumlarına sahip öğretmenlerin 3.47 ; lisansüstü öğrenim durumlarına sahip öğretmenlerin 3,39 olarak belirlenmiştir. Puan ortalamalarına ilişkin $t$ değeri ise 0,97 olarak tespit edilmiştir. Elde edilen $\mathrm{t}$ değeri dikkate alınarak öğretmen algılarına göre okul yöneticilerinin müzakere becerileri alt boyutlarından çözümden yana olma puan ortalamaları, öğretmenlerin öğrenim durumu değişkenine göre anlamlı bir şekilde farklılaşmadığı görülmüştür $(p>0,05)$.

Okul yöneticilerinin etkileme davranışları alt boyut puan ortalamaları ile müzakere becerileri alt boyut puan ortalamaları arasındaki ilişkiyi belirlemek üzere korelasyon analizi yapılmıştır. Elde edilen bulgular Tablo 8'de gösterilmektedir. 
Tablo 8. Katılımcıların Etkileme Davranışları ve Müzakere Becerileri İlişkisine Yönelik Korelasyon Verileri

\begin{tabular}{|l|c|c|c|}
\hline \multirow{2}{*}{ Etkileme Davranışları Alt Boyutları } & \multicolumn{2}{c|}{ Müzakere Becerileri Alt Boyutları } \\
\cline { 2 - 4 } & & Güven Ortamı Oluşturma & Çözümden Yana Olma \\
\hline Akı1 Yoluyla İkna Etme & $\mathrm{r}$ & $.46^{*}$ & $.43^{*}$ \\
\hline Karşılık Verme & $\mathrm{r}$ & $.16^{*}$ & $.18^{*}$ \\
\hline Teşvik Edici Talepte Bulunma & $\mathrm{r}$ & $.50^{*}$ & $.51^{*}$ \\
\hline Kurallara Uygunluk & $\mathrm{r}$ & $.29^{*}$ & $.29^{*}$ \\
\hline Bilgilendirme & $\mathrm{r}$ & $.40^{*}$ & $.39^{*}$ \\
\hline Baskı Yapma & $\mathrm{r}$ & $-.24^{*}$ & $-.23^{*}$ \\
\hline İş Birliği Yapma & $\mathrm{r}$ & $.52^{*}$ & $.50^{*}$ \\
\hline Takdir Etme & $\mathrm{r}$ & $.45^{*}$ & $.42^{*}$ \\
\hline İstişarede Bulunma & $\mathrm{r}$ & $.52^{*}$ & $.51^{*}$ \\
\hline Kişisel Yakınlığı Kullanma & $\mathrm{r}$ & .03 & .03 \\
\hline Başkalarıyla Koalisyon Kurma & $\mathrm{r}$ & $.11^{*}$ & $.11^{*}$ \\
\hline
\end{tabular}

$* \mathrm{P}<.05$

Tablo 8'den anlaşılacağı gibi, öğretmen algılarına göre okul yöneticilerinin müzakere becerileri değişkeninin alt boyutlarıyla etkileme davranışları değişkeninin alt boyutlarından sırasıyla istişarede bulunma, iş birliği yapma, teşvik edici talepte bulunma, akıl yoluyla ikna etme, takdir etme, bilgilendirme, kurallara uygunluk, karşıl1k verme ve başkalarıyla koalisyon kurma alt boyutları arasında pozitif yönde anlamlı bir ilişki olduğu görülmektedir $(p<0,05)$. Öğretmen algılarına göre okul yöneticilerinin müzakere becerileri değişkeninin alt boyutlarıyla etkileme davranışları değişkeninin alt boyutlarından kişisel yakınlığı kullanma alt boyutu arasında anlamlı bir ilişki bulunmamıştır ( $p>0,05)$. Öğretmen algılarına göre okul yöneticilerinin müzakere becerileri değişkeninin alt boyutlarıyla etkileme davranışları değişkeninin alt boyutlarından baskı yapma alt boyutu arasında negatif yönde anlamlı bir ilişki tespit edilmiştir ( $p<0,05)$. Öğretmen algılarına göre okul yöneticilerinin etkileme davranışlarının müzakere becerilerine etkisini belirlemek üzere Regresyon analizine başvurulmuştur. Elde edilen bulgular Tablo 9 ve Tablo 10'da gösterilmiştir.

Tablo 9. Katılımcıların Etkileme Davranışları ve Güven Ortamı Oluşturma Altboyutına Yönelik Regrasyon Verileri

\begin{tabular}{|c|c|c|c|c|c|c|c|c|}
\hline Değişken & $\mathbf{R}^{2}$ & $\mathbf{F}$ & $\mathbf{p}$ & Boyutlar & $\boldsymbol{\beta}$ & $\mathbf{t}$ & $\mathbf{p}$ & VIF \\
\hline \multirow{11}{*}{$\begin{array}{l}\text { Etkileme } \\
\text { Davranışları }\end{array}$} & \multirow{11}{*}{0,392} & \multirow{11}{*}{42,48} & \multirow{11}{*}{$\mathbf{0 , 0 0}$} & Ak1l Yoluyla İkna Etme & 0,380 & 3,55 & 0,00 & 1,99 \\
\hline & & & & Karş1lık Verme & $-0,008$ & $-0,09$ & 0,925 & 1,44 \\
\hline & & & & Teşvik Edici Talepte Bulunma & 0,370 & 3,12 & 0,002 & 2,40 \\
\hline & & & & Kurallara Uygunluk & $-0,050$ & $-0,52$ & 0,603 & 1,64 \\
\hline & & & & Bilgilendirme & 0,116 & 1,15 & 0,250 & 2,16 \\
\hline & & & & Bask1 Yapma & $-0,291$ & $-3,79$ & 0,000 & 1,21 \\
\hline & & & & İş birliği Yapma & 0,414 & 3,52 & 0,000 & 2,60 \\
\hline & & & & Takdir Etme & 0,225 & 2,36 & 0,018 & 2,11 \\
\hline & & & & İstişarede Bulunma & 0,336 & 2,87 & 0,004 & 2,79 \\
\hline & & & & Kişisel Yakınlığı Kullanma & 0,005 & 0,051 & 0,959 & 1,85 \\
\hline & & & & Başkalarıyla Koalisyon Kurma & $-0,040$ & $-0,39$ & 0,693 & 1,82 \\
\hline
\end{tabular}

Bağımlı Değişken: Okul yöneticilerinin Güven Ortamı Oluşturma puanları

Tablo 9 incelendiğinde, öğretmen algılarına göre okul yöneticilerinin müzakere becerileri alt boyutlarından güven ortamı oluşturma alt boyut puanlarındaki değişkenliğin \%39,2'sini yordamaktadır. Etkileme davranışlarının alt boyutları arasında incelendiğinde öğretmen algılarına göre okul yöneticilerinin müzakere becerileri alt boyutlarından güven ortamı oluşturma alt boyut puanını sırasıyla etkileme davranışlarının bask yapma, akl yoluyla ikna etme, iş birliği yapma, teşvik edici talepte bulunma, istişarede bulunma ve takdir etme alt boyutları yordadığı tespit edilmiştir $(\mathrm{p}<0,05)$. Öğretmen algılarına göre okul yöneticilerinin müzakere becerileri alt boyutlarından güven ortamı oluşturma alt boyutunu, etkileme davranışlarının karşılık verme, 
IRMAK, Adnan ve YILMAZ, Ercan - Okul Yöneticilerinin Müzakere Becerilerinin Yordayıcısı Olarak Etkileme Davranışları

kurallara uygunluk, bilgilendirme, kişisel yakınlığı kullanma ve başkalarıyla koalisyon kurma alt boyutları anlamlı bir şekilde yordamadığ gözlemlenmiştir $(\mathrm{p}>0,05)$.

Tablo 10. Katılımcıların Etkileme Davranışları ve Çözümden Yana Olma Altboyutına Yönelik Regrasyon Verileri

\begin{tabular}{|c|c|c|c|c|c|c|c|c|}
\hline Değișken & $\mathbf{R}^{2}$ & $\mathbf{F}$ & $\mathbf{p}$ & Boyutlar & $\bar{\beta}$ & $\mathbf{t}$ & $\bar{p}$ & VIF \\
\hline \multirow{11}{*}{$\begin{array}{l}\text { Etkileme } \\
\text { Davranışları }\end{array}$} & \multirow{11}{*}{0,364} & \multirow{11}{*}{37,72} & \multirow{11}{*}{$\mathbf{0 , 0 0}$} & Ak1l Yoluyla İkna Etme & 0,161 & 2,19 & 0,028 & 1,99 \\
\hline & & & & Karş1lik Verme & 0,076 & 1,38 & 0,168 & 1,44 \\
\hline & & & & Teşvik Edici Talepte Bulunma & 0,325 & 4,02 & 0,000 & 2,40 \\
\hline & & & & Kurallara Uygunluk & 0,027 & 0,42 & 0,675 & 1,64 \\
\hline & & & & Bilgilendirme & 0,048 & 0,70 & 0,481 & 2,16 \\
\hline & & & & Bask1 Yapma & $-0,190$ & $-3,62$ & 0,000 & 1,21 \\
\hline & & & & İş birliği Yapma & 0,249 & 3,09 & 0,002 & 2,60 \\
\hline & & & & Takdir Etme & 0,045 & 0,69 & 0,485 & 2,11 \\
\hline & & & & İstişarede Bulunma & 0,271 & 3,39 & 0,001 & 2,79 \\
\hline & & & & Kişisel Yakınlığı Kullanma & 0,031 & 0,43 & 0,661 & 1,85 \\
\hline & & & & Başkalarıyla Koalisyon Kurma & $-0,068$ & $-0,98$ & 0,323 & 1,82 \\
\hline
\end{tabular}

Bağımlı Değişken: Okul yöneticilerinin Çözümden Yana Olma puanları

Tablo 10 incelendiğinde, öğretmen algılarına göre okul yöneticilerinin müzakere becerileri alt boyutlarından çözümden yana olma alt boyut puanlarındaki değişkenliğin \%36,4 ünü yordamaktadır. Öğretmen algılarına göre etkileme davranışlarının alt boyutları arasında incelendiğinde, okul yöneticilerinin müzakere becerileri alt boyutlarından çözümden yana olma alt boyut puanını sırasıyla etkileme davranışlarının teşvik edici talepte bulunma, baskı yapma, istişarede bulunma, iş birliği yapma ve akal yoluyla ikna etme alt boyutları açıklamaktadır $(\mathrm{p}<0,05)$. Öğretmen algılarına göre okul yöneticilerinin müzakere becerileri alt boyutlarından çözümden yana olma alt boyutunu, etkileme davranışlarının karşıllk verme, kurallara uygunluk, bilgilendirme, kişisel yakınlı̆̆ kullanma, takdir etme ve başkalarıyla koalisyon kurma alt boyutları anlamlı bir şekilde açıklamadığı bulgulanmıştır ( $\mathrm{p}>0,05)$.

\section{SONUÇ VE ÖNERILER}

Araştırmada okul yöneticilerinin kadın öğretmenlere karşı daha yapıcı ve müzakereye açık bir tutum içinde olduğu, erkek öğretmenlerde ise bu durumun aksi yönde gerçekleştiği sonucuna varılmıştır. Okul yöneticileri müzakere sürecinde erkek öğretmenlere yönelik okulda güven ortamı oluşturmalı, onlara çözümden yana olduklarını hissettirmelidir. Alanyazında yapılan bazı araştırmalarda (Özgan vd., 2010; Coşkun, 2013; Sarıçay, 2019) öğretmen algılarına göre okul yöneticilerinin müzakere becerileri cinsiyet durumu değişkenine göre anlamlı bir fark bulunmamıştır. Yılmaz (2014) çalışmasında, okul yöneticilerinin müzakere becerileri cinsiyet durumu değişkenine göre anlamlı bir farklılaşma bulmuştur. Ancak, araştırmada erkek öğretmenlerin kadın öğretmenlere göre okul yöneticilerinin müzakere becerileri algılamaları daha yüksek olduğu görülmüştür. Her iki araştırmada elde edilen bulguların farklı olmasının öğretmenlerin yaşadıkları coğrafi bölge farklılı̆̆ından kaynaklanabileceği düşünülmektedir. Araştırma evreninde yer alan okullarda görev yapan okul yöneticilerinin büyük çoğunluğunun erkek olması, okul yöneticilerinin kadın öğretmenlere karşı daha yapıcı ve müzakereye açık bir tutum içinde olduğu kanısına varılmıştır.

Araştırma, öğretmenlerin çalıştığı okul türü kademesi yükseldikçe (okul öncesi eğitimden ortaöğretime doğru), öğretmen algılarına göre okul yöneticilerinin müzakereye başvurma eğilimlerinin kademeli olarak azaldığını ortaya çıkarmaktadır. Okul yöneticilerinin müzakere becerilerini sergileme düzeyleri ortaokul ve liselerde arttırılmalıdır. Eğitim kademelerinde görev yapan öğretmenlerin aidiyet duygularını geliştirecek, onları etkileyecek davranışlar sergilenmelidir. Alanyazında yapılan araştırmalarda (Yıldırım vd., 2013; Yılmaz, 2014; Sarıçay, 2019) öğretmenlerin çalıştıkları okul türü değişkeninin okul yöneticilerinin müzakere becerilerinde etkili olmadığı sonucuna rastlanmıştır. Araştırma bulgularının farklı çıkmasının yapılan araştırmalarda anaokullarının okul türü olarak dâhil edilmemesinden kaynaklanabileceği düşünülmektedir.

Araştırmada öğretmen algılarına göre okul yöneticilerinin müzakere becerilerinde öğretmenlerin kıdem durumu değişkenlerine göre bir farklılaşma görülmediği sonucuna varılmışır. Alanyazında benzer sonuçlara sahip araştırmalara (Özgan vd., 2010; Coşkun, 2013) rastlanabildiği gibi farklı sonuçlara sahip araştırmalara da (Yıldırım vd., 2013; Yılmaz, 2014; Sarıçay, 2019) rastlamak mümkündür. Farklı sonuçların ortaya çıkması, araştırma örneklemlerinin farklı büyüklük ve coğrafyalarda olmasından kaynaklanabileceğini düşünülmektedir. 
Araştırmada öğretmen algılarına göre okul yöneticilerinin müzakere becerilerinde öğretmenlerin öğrenim durumu değişkenlerine göre bir farklılaşma görülmediği gözlemlenmiştir. Benzer sonuçlar, Yılmaz (2014) ve Coşkun'un (2013) yaptığı araştırmalarda da görülmektedir. Araştırmaya, öğretmenlerin bulunduğu okulda çalışma sürelerininin dâhil edilmemesi ileriki çalışmalarda giderilebilir bir eksiklik olarak görülmektedir.

Araştırmada, öğretmen algılarına göre okul yöneticilerinin müzakere sürecinde sergilediği etkileme davranışları alt boyutlarından sırasıyla istişarede bulunma, iş birliği yapma, teşvik edici talepte bulunma, akıl yoluyla ikna etme, takdir etme, bilgilendirme, kurallara uygunluk, karş1lık verme ve başkalarıyla koalisyon kurma davranışlarının müzakere becerileriyle olumlu yönde ilişkili olduğu, baskı yapma etkileme davranışının ise olumsuz yönde ilişkili olduğu sonucuna varılmıştır. Okul yöneticilerinin kişsel yakınlığı kullanma etkileme davranışıyla sergilediği müzakere becerileri arasında öğretmen algılarına göre bir ilişki bulunamamıştır.

Öğretmen algılarına göre okul yöneticilerinin müzakere becerileri ile etkileme davranışları alt boyutları arasındaki ilişki incelendiğinde, okul yöneticileri öğretmenlere mantıksal gerekçeler sunup, problemin nedenleri ile birlikte çözüm önerileri sunması okul yöneticilerinin müzakere becerileriyle ilişkili olduğu sonucuna varılmıştır. Ayrıca okul yöneticileri öğretmenlerle birlikte hareket edip iş birliği içinde olması, öğretmenlerin değer yargılana önem vererek teşvik edici talepte bulunması, öğretmenlere danışarak karar alması, öğretmenlerin başarılarını takdir etmesi, öğretmenlere süreç sonunda elde edeceği kazanımlar hakkında bilgi vermesi, öğretmenlere verilen görevlerin yasal ve hukuka uygun olduğunun belirtilmesi, öğretmenlere verilecek görev öncesinde bir takım iyiliklerde bulunması, öğretmenlerin önemsediği kişilerden yardım alması okul yöneticilerinin müzakere beceriyle ilişkili olduğu sonucuna varılmıştır. Öte yandan öğretmen algılarına göre okul yöneticilerinin müzakere sürecinde başvurduğu baskı yapma davranışıyla okul yöneticilerinin müzakere becerileryle olumsuz yönde ilişkili olduğu kanısına varılmıştır. Öğretmen algılarına göre okul yöneticilerinin etkileme davranışları değişkeninin alt boyutlarından kişisel yakınlığı kullanma ile okul yöneticilerinin müzakere becerileri değişkeninin alt boyutları arasında anlamlı bir ilişki bulunmadığı gözlemlenmiştir. Dolayısıyla okul yöneticilerinin müzakere sürecinde karşı tarafı etkilemeye çalışırken akrabalık veya dostluklarını kullanmadığını göstermektedir.

Araştırma, öğretmen algılarına göre okul yöneticilerinin müzakere sürecinde başvurduğu etkileme davranışları sonuçlarını şu şekilde ortaya çıkarmaktadır. Öğretmen algılarına göre okul yöneticilerinin müzakere sürecinde en fazla sergiledikleri etkileme davranışlarından baskı yapma davranışı, okul yöneticilerinin güven ortamı oluşturma ve çözümden yana olma becerilerine katkı sunmadığını göstermiştir. Okul yöneticileri müzakere sürecinde öğretmenlere kendi fikirlerini dayatmamalıdır. Öğretmenlere rahat bir ortam sunmaları gerekmektedir. Öğretmen algılarına göre okul yöneticilerinin baskı yapma etkileme davranışından sonra başvurdukları akıl yoluyla ikna etme etkileme davranışında yöneticiler, öğretmenleri mantıksal gerekçeler ortaya atarak müzakere sürecinde güven ortamı oluşturma ve çözümden yana olma becerileri sergiledikleri gözlemlenmiştir. Okul yöneticileri, iş birliği yapma etkileme davranışında öğretmenlerle birlikte hareket ederek güven ortamı oluşturma ve çözümden yana olma becerilerini sergilemiştir. Öğretmen algılarına göre müzakere sürecinde okul yöneticilerinin sergilemiş oldukları takdir etme davranışı, yöneticilerin müzakere sürecinde güven ortamı oluşturma becerilerine katkı sunarken çözümden yana olma becerilerinde katkı sunmadığı sonucuna varılmıştır. Öğretmen algılarına göre okul yöneticilerinin müzakere sürecinde sergilemiş olduğu karşılık verme etkileme davranış1, okul yöneticilerinin müzakere becerilerini etkilemediği görülmektedir. Cialdini’ye (2001:46) göre toplumlar kültürlerinde barındırdığı borçlu kalma - minnet altında kalma duygusu, kendisine yapılmış bir iyiliği karşılıksız bırakmama şeklinde algılanmaktadır. Bu durumun okul yöneticileri tarafından müzakere sürecinde sergilenen güven ortamı oluşturma ve çözümden yana olma becerilerinde tercih edilmediği görülmektedir. Kurallara uygunluk etkileme davranışında okul yöneticileri tarafindan öğretmenlere verilen görevle ilgili müzakere sürecinde yasal dayanak hakkında yeterince açıklama yapılmadığı görülmektedir. Bilgilendirme etkileme davranışında, öğretmen algılarına göre yöneticiler, bir görevi veya bir durumu öğretmenlerle müzakere ederken verilen görevin öğretmene ve kuruma neler kazandırılabileceği hakkında yeterli bilgi vermedikleri sonucuna varılmıştır. Okul yöneticilerinin müzakere sürecinde güven ortamı oluşturma ve çözümden yana olma becerilerini sergilerken kişisel yakınlığı kullanma etkileme davranışına başvurmadığı görülmektedir. Bu durum, okulda yöneticilerin resmi bir tutum içinde oldukları şeklinde düşünülmektedir. Okul yöneticilerinin müzakere sürecinde hem güven ortamı oluşturma hem de çözümden yana olma müzakere becerilerinde başkalarıyla koalisyon kurmadığı gözlemlenmektedir. Yukl (2013:206), başkalarıyla koalisyon kurma etkileme davranışına aynı pozisyonda veya eş göreve sahip kişiler tarafından başvurulması gerektiğini önermiştir. Okulun hiyerarşik bir düzene sahip olması, verilen görevlerin daha çok emir komuta şeklinde gerçekleşleşmesine dolayısıyla okul yöneticileri öğretmenlerin önemsediği kişileri sürece dâhil etmediği düşünülmektedir. 
Sonuç olarak öğretmen algılarına göre okul yöneticilerinin müzakere becerilerini etkileme davranışlarından akıl yoluyla ikna etme, iş birliği yapma, teşvik edici talepte bulunma, istişarede bulunma, takdir etme davranışları yordadığı sonucuna varılmıştır. Dolayısıyla okul yöneticileri okulda bu davranışların segilemesi önerilmektedir. Öte yandan öğretmen algılarına göre okul yöneticilerinin müzakere becerilerini etkileme davranışlarından karşılık verme, kurallara uygunluk, bilgilendirme, başkalarıyla koalisyon kurma davranışları her ne kadar yordamasa da iki değişken arasında düşük düzeyde olumlu yönde ilişki olduğunu göz önünde bulundurulmalıdır. Öğretmen algılarına göre okul yöneticilerinin müzakere becerilerini etkileme davranışlarından kişisel yakınlığı kullanma davranışı yordamadığı görülmektedir. Ayrıca okul yöneticilerin müzakere becerileriyle kişisel yakınlğı kullanma etkileme davranışı araşında bir ilişkiye de rastlanılmamıştır. Dolayısıyla okul yöneticileri müzakere becerilerini geliştirirken kişisel yakınlığı kullanma etkileme davranışını resmi bir kurum olan okulda sergilemekten kaçındığ etkileme davranışında öğretmen algılarına göre okul yöneticilerinin müzakere becerileriyle olumsuz yönde ilişkili olduğu aynı zamanda yordadığı görülmektedir. Baskı yapma etkileme davranışı, karşı tarafı tehdit ederek baskılamak şeklinde tanımlanmaktadır (Yukl vd., 2013:206). Dolayısıyla öğretmen algılarına göre okul yöneticilerinin müzakere sürecinde sahip olduğu güç unsurlarını kullanarak öğretmenleri baskıladığı düşünülmektedir. Okul yöneticileri hem güven ortamı oluşturmada hem de çözümden yana olma müzakere becerileri sergilerken baskılayıcı bir tutum sergilememesi gerekir.

\section{KAYNAKÇA}

ADE, Valentin, SCHUSTER, Carolin, HARINCK, Fieke ve TRÖTSCHEL, Roman (2018), "Mindset-Oriented Negotiation Training (MONT): Teaching More Than Skills And Knowledge", Frontiers in Psychology, S.5(9), ss.1-13.

ATEŞ, Ahmet (2020), "Müzakere Yaklaşımları Bağlamında Sert, Yumuşak ve Prensipli Müzakerelerin Analizi”, Türkiye Sosyal Araştırmalar Dergisi, S.115-120(1), ss.111-126.

AYPAY, Ahmet (2015), Araştırma Yöntemleri Desen ve Analiz, Anı Yayıncılık, Ankara, 2.Baskı.

BÜYÜKÖZTÜRK, Şener, KILIÇ ÇAKMAK, Ebru, AKGÜN, Özcan Erkan, KARADENIZ, Şirin ve DEMIREL, Funda (2016), Bilimsel Araştırma Yöntemleri, Pegem Akademi Yayınları, Ankara, 22.Bask1.

CAN, Abdullah (2018), SPSS İle Bilimsel Araştırma Sürecinde Nicel Veri Analizi, Pegem Akademi Yayınları, Ankara, 6.Baskı.

CARNEVAlE, Peter J. ve PRUITT, Dean G. (1992), "Negotiation and Mediation", Department of Psychology, University of Illinois at Urbana-Champ, S.532(43), ss.531-582.

CEMALOĞLU, Necati ve ŞAHİN, Fatih (2017), “Birey, Örgüt ve Yönetim”, Örgütsel Davranış ve Yönetimi (Ed. Necati Cemaloğlu ve Servet Özdemir), Pegem Akademi Yayınları, Ankara, ss.1-31.

CIALDINI, Robert B. (2019), İknanın Psikolojisi Teori ve Pratik Bir Arada (Çev. Yasemin Fletcher), Kültür Sanat Basimevi, İstanbul.

COŞKUN, Gökhan (2013), “İlköğretim Okullarında Çalışan Öğretmenlerin Müzakere Algılamalarının İş Tatmini Üzerine Etkisi: Ankara Keçiören Örneği”, Yayımlanmamış Yüksek Lisans Tezi, Gazi Üniversitesi Eğitim Bilimleri Enstitüsü, Ankara.

DAĞLI, Emine (2015), “ïlköğretim Okullarında Müdürlerin Kullandıkları Etkileme Taktiklerinin Öğretmenlerin Örgütsel Vatandaşlık Davranışları ve Okul Farkındalı̆̆ı ile Iliş̧kisi”, Yayımlanmamış Doktora Tezi, Gazi Üniversitesi Eğitim Bilimleri Enstitüsü, Ankara.

DAĞLI, Emine ve ÇALIK, Temel (2016), “ïlköğretim Okullarında Müdürlerin Kullandıkları Etkileme Taktiklerinin Öğretmenlerin Örgütsel Vatandaşlık Davranışları ve Okul Farkındalığı ile Iliş̧isi”, Pegem Akademi Yayınları, S.22(1), ss.29-58.

ERDEM ARTAN, İnci (2002), “Çatışma Yönetimi”, Örgütte Kişisel Gelişim (Ed. A. Esra Aslan), Nobel Yayınları, Ankara, ss.201-236.

ERDOĞAN, İrfan (2006), Eğitim ve Okul Yönetimi, Sistem Yayınc1lı, Ankara, 6.Bask1. 
ERKUŞ, Ahmet ve TABAK, Akif (2008), "İş Yaşamında Müzakereler: Kamu ve Özel Sektör Çalışanlarıyla İlgili Karşılaş̧ırmalı Bir Araştırma", Selçuk Üniversitesi Sosyal Bilimler Enstitüsü Dergisi, S.20, ss.397-418.

GÖKYER, Necmi (2017), "Örgütsel Çatışma”, Örgütsel Davranış ve Yönetimi (Ed. Servet ÖZDEMİR, Necati CEMALOĞLU), Pegem Akademi Yayınları, Ankara, ss.391-420.

GÖZÜ, Cüneyt (2012), "Influence Tactics and Leadership Effectiveness in Turkey and USA: Mediating Role of Subordinate Commitment", New York: A Dissertation Submitted To The University At Albany, State University of NewYork

GÜNEY, Gökhan (2016), “Etkileme Taktiklerinin Astın Örgüte Bağlllı̆̆ına Etkisinde Lidere Bă̆lılı̆̆ın ve Güvenin Rolü”, Yayımlanmamış Yüksek Lisans Tezi, Kara Harp Okulu, Ankara.

İSPIR, Nevzat Bilge (2008), "Yöneticilerin Kullandığl Etki Taktikleri ve Kurum Kültürü: Uygulama ve Yönetimsel Etkileme İçin Model Önerisi”, Yayımlanmamış Doktora Tezi, Anadolu Üniversitesi Sosyal Bilimler Enstitüsü, Eskişehir.

KARASAR, Niyazi (2016), Bilimsel Araştırma Yöntemleri, Nobel Yayınc1lı, Ankara, 33.Bask1.

KURU ÇETIN, Saadet (2013), “Okul Yöneticileri ve Öğretmenlerin Birbirlerini Etkileme Taktiklerinin Örgütsel Adalet ile Illişkisi”, Yayımlanmamış Doktora Tezi, Ankara Üniversitesi Sosyal Bilimler Enstitüsü, Ankara.

KÜDEN, Murat (2016), Yöneticiler İçin Etkin Müzakere Teknikleri, ATS Akademi Yayınları, Antalya.

ÖZDEMİR YAYLACI, Gaye (2006), "Organizasyonlarda Kişilerarası İlişkilerde Etki Taktikleri ve Kullanımına İlişkin Literatür Çalışması”, Ahmet Yesevi Üniversitesi Bilig Türk Dünyası Sosyal Bilimler Dergisi, S.36, ss.93-112.

ÖZGAN, Habib, ÇELIK, Çiğdem ve BOZBAYINDIR, Fatih (2010), “İlköğretim Okulu Müdürlerinin Müzakere Becerilerinin İncelenmesi”, Bayburt Üniversitesi Eğitim Fakültesi Dergisi, S.2(5), ss.95-103.

ÖZGAN, Habib, ÇELIK, Çiğdem ve BOZBAYINDIR, Fatih (2011), "Müzakere Beceri Ölçeği: Geçerlilik ve Güvenirlik Çalışması", Elektronik Sosyal Bilimler Dergisi, S.10(36), ss.65-76.

SARIÇAY, Serkut (2019), “Okul Yöneticilerinin Müzakere Becerileri ile Öğretmenlerin Muhalif Davranışları Arasındaki İlişki”, Yayımlanmamış Yüksek Lisans Tezi, Pamukkale Üniversitesi Sosyal Bilimler Enstitüsü, Denizli.

SIMMEL, Georg (1896), "Sosyolojinin Konusu Olarak Üstünlük ve Itaat”, Amerikan Sosyoloji Dergisi, S.2(2), ss.167-189.

TAŞÇI, Deniz ve EROĞLU, Erhan (2007), "Yöneticinin Kişilik Özellikleri ile Kullandıkları İkna ve Etkileme Taktiklerinin Kullanım Sıklı̆̆ı Arasındaki İlişkinin Değerlendirilmesi”, Selçuk Üniversitesi Sosyal Bilimler Enstitüsü Dergisi, S.17, ss.533-546.

UÇAN, Murat Yusuf (2014), "Müzakereci Olarak Yönetici Asistanı: Yeni Bir Kariyer Mi?”, Electronic Journal of Vocational Colleges, S.(Bürokon Özel Sayıs1), ss.379-395.

ÜNAL, Ali ve ÖZASLAN, Gökhan (2017), “Okul Yöneticilerinin Maarif Müfettişlerine Yönelik Etkileme Taktikleri”, Mersin Üniversitesi Ĕ̆itim Fakültesi Dergisi, S.13(1), ss.176-195.

YALÇIN, Mikail, AYPAY, Ahmet ve BOYACI, Adnan (2020), "Okul Müdürlerinin Bürokrasi ile Imtihanı”, Kuram ve Uygulamada Eğitim Yönetimi Dergisi, S.26(1), ss.203-260.

YILDIRIM, Muhamet Cevat, KAYA, Ahmet, BALAY, Refik ve YILMAZ, Salih (2013), "Okul Müdürlerinin Müzakere Becerilerine Illişkin Bir Analiz", Turkish Studies-International Periodical for The Languages, Literature and History of Turkish or Turkic, S.8(8), ss.2277-2289.

YILMAZ, Salih (2014), “Okul Yöneticilerinin Çatışmayı Yönetme Stilleri İle Müzakere Becerileri Arasındaki İlişki”, Yayımlanmamış Yüksek Lisans Tezi, Harran Üniversitesi Sosyal Bilimler Enstitüsü, Şanlıurfa.

YUKL, Gary (2013), Leadership in Organizations, Pearson Prentice Hall, New Jersey, 8th Edition.

YUKL, Gary, SEIFERT, Charles F. ve CHAVEZ, Carolyn (2008), "Validation of The Extended Influence Behavior Questionnaire”, The Leadership Quarterly, S.19, ss.609-621. 